\title{
ANALISA FUNGSI PRODUKSI DAN EFISIENSI TEKNIK PADA USAHATANI JAGUNG
}

\author{
Desy Cahyaning Utami* \\ * Dosen Fakultas Pertanian Universitas Yudharta Pasuruan \\ Imail: d2.decy@gmail.com
}

\begin{abstract}
ABSTRAK
Komoditas jagung (Zea mays) merupakan salah satu komoditas strategis karena merupakan bahan makanan penghasil karbohidrat kedua setelah padi. Permasalahan utama dalam usahatani jagung adalah rendahnya produksi jagung karena kepemilikan luas lahan yang terbatas oleh petani, penggunaan benih yang berlebihan, penggunaan pupuk yang berlebihan. Penelitian ini bertujuan untuk: (1) Menganalisis faktor-faktor produksi yang mempengaruhi tingkat produksi pada usahatani jagung, dan (2) Menganalisis tingkat efisiensi penggunaan faktor-faktor produksi pada usahatani jagung.

Berdasakan hasil analisis yang telah dilakukan, maka hasil yang diperoleh dari penelitian ini, faktor produksi yang berpengaruh nyata pada usahatani jagung adalah luas lahan, benih, dan pupuk kandang. Pengukuran efisiensi menggunakan Data Envelopment Analysis (DEA) menunjukkan bahwa usahatani jagung di daerah penelitian belum mampu mencapai performansi tingkat efisiensi yang full-efisien secara teknis, karena rata-rata efisiensi teknis yang dicapai sebesar $87 \%$, dengan kisaran antara 40,3\% hingga $100 \%$. Nilai inefisiensi teknis rata-rata adalah sebesar $13 \%$. Hal ini mengindikasikan masih adanya peluang bagi petani jagung untuk untuk meningkatkan hasil produksinya dengan mengoptimalkan faktor-faktor produksi yang dimiliki.
\end{abstract}

Kata Kunci : Jagung, faktor produksi, efisiensi teknik

\section{PENDAHULUAN}

Pembangunan pertanian periode tahun 2005-2009 diarahkan pada terwujudnya pertanian tangguh untuk pemantapan ketahanan pangan, peningkatan nilai tambah dan daya saing produk pertanian, serta peningkatan kesejahteraan petani melalui salah satu program utama yaitu program peningkatan ketahanan pangan (Departemen Pertanian, 2005). Tujuan program peningkatan ketahanan pangan adalah untuk memfasilitasi terjaminnya masyarakat dalam memperoleh pangan yang cukup dan tercapainya sasaran ketersediaan pangan tingkat nasional. Komoditas jagung tergolong komoditas yang strategis karena memenuhi kriteria antara lain memiliki pengaruh terhadap harga komoditas pangan lainnya, memiliki prospek yang cerah, memiliki kaitan ke depan dan ke belakang yang cukup baik (Suwito, 1996). Dari segi konsumsi, jagung merupakan substitusi bagi beras dan ubi kayu. Bagi orang Indonesia jagung merupakan bahan makanan pokok kedua 
setelah beras. Sedangkan dari segi produksi, jagung saling berkompetisi dengan pangan lainnya dalam penggunaan sumber daya lahan terutama pada lahan kering. Dengan demikian dapat dikatakan bahwa baik langsung maupun tidak langsung perkembangan harga jagung akan ikut mempengaruhi harga komoditaskomoditas lain secara umum atau setidaknya bagi beberapa komoditas tanaman pangan. Peningkatan kebutuhan jagung di dalam negeri berkaitan erat dengan perkembangan industri pangan dan pakan. Untuk pangan, jagung lebih banyak dikonsumsi dalam bentuk produk olahan atau bahan setengah jadi seperti bahan campuran pembuatan kue, bubur instan, campuran kopi dan produk rendah kalori. Konsumsi per kapita jagung dalam negeri untuk pangan mencapai $15 \mathrm{~kg}$, sedangkan untuk pakan mencapai 22,5 kg (Suprapto dan Marzuki, 2005). Hingga saat ini produksi jagung di dalam negeri belum mampu memenuhi kebutuhan sehingga sebagian diimpor.

Untuk dapat meningkatkan efisiensi dan produktivitas maka diperlukan berbagai informasi terkait dengan faktorfaktor yang dapat mempengaruhi efisiensi dan produktivitas itu sendiri. Faktor penting dalam pengelolaan sumberdaya produksi adalah faktor alam (lahan), modal, tenaga kerja, dan faktor manajemen (Soekartawi, 1990). Oleh karena itu penelitian mengenai faktor-faktor yang mempengaruhi produksi tidak terlepas dari faktor penggunaan luas lahan maupun input usahatani. Berdasarkan uraian tersebut sangat penting dilakukan penelitian mengenai seberapa jauh petani jagung mampu mengalokasikan sumberdaya yang dimiliki untuk memperoleh produksi yang maksimum sehingga dapat meningkatkan pendapatan petani.

Pendekatan yang digunakan untuk analisis efisiensi teknis penggunaan faktor produksi pada usahatani jagung menggunakan metode DEA (Data Envelopment Analysis). Dengan demikian penelitian ini dilakukan dengan tujuan: (1) Menganalisis Faktor-faktor produksi yang mempengaruhi tingkat produksi di daerah penelitian, (2) Menganalisis tingkat efisiensi penggunaan faktor-faktor produksi pada usahatani jagung di daerah penelitian.

\section{METODE PENELITIAN}

\section{Lokasi dan Waktu Penleitian}

Lokasi penelitian dilakukan secara sengaja (purposive) yaitu di Desa Sukolilo Kecamatan Wajak Kabupaten Malang, dengan pertimbangan bahwa Desa Sukolilo merupakan salah satu desa yang memiliki karakteristik masyarakat yang sebagian besar bermata pencaharian sebagai petani. Selain itu, pemilihan lokasi didasarkan atas 
pertimbangan bahwa di Desa Sukolilo Kecamatan Wajak mempunyai sumberdaya alam yang potensial untuk pengembangan jagung dibandingkan dengan kecamatan lain,. Oleh karena itulah, desa ini dijadikan lokasi studi kasus bagi penelitian ini. Penelitian ini dilakukan mulai bulan Juli hingga Desember 2010. Pemilihan responden (sample) yang digunakan pada penelitian ini adalah 35 orang petani jagung yang dipilih secara acak sederhana (simple random sampling).

\section{Data dan Sumber Data}

Data yang digunakan dalam penelitian ini adalah data primer dan data sekunder. Data primer diperoleh melalui wawancara, dengan menggunakan daftar pertanyaan dalam bentuk pertanyaan terstruktur (kuisioner), terhadap 35 petani jagung di daerah penelitian. Data sekunder berupa data atau dokumen yang berasal dari buku, internet, instansi terkait, penelitian terdahulu yang terkait dengan bahan penelitian. Data yang diperoleh diantaranya adalah data produksi jagung dari BPS, dan profil Desa Sukolilo.

\section{Metode Analisis}

Metode analisis dalam penelitian ini mencakup analisis faktor-faktor produksi yang berpengaruh terhadap usahatani jagung dan efisiensi teknis usahatani jagung. Analisis regresi fungsi produksi digunakan untuk menguji faktor- faktor produksi yang berpengaruh nyata terhadap hasil produksi tanaman jagung di Desa Sukolilo Kecamatan Wajak Kabupaten Malang. Model fungsi produksi yang digunakan adalah Cobb-Douglas. Fungsi produksi ini sesuai dengan produksi di bidang pertanian. Dari kerangka konsep penelitian dijelaskan bahwa faktor-faktor produksi yang digunakan dalam berusahatani jagung dan bepengaruh terhadap produksi adalah luas lahan, benih, pupuk urea, pupuk kandang, pestisida, dan tenaga kerja. Fungsi produksi CobbDouglas dapat dinyatakan sebagai berikut : $\operatorname{Ln} Y=\operatorname{Ln} \beta 0+\beta 1 \operatorname{LnX} 1+\beta 2 \operatorname{LnX} 2+$ $\beta 3 \operatorname{LnX} 3+\ldots+\beta n \operatorname{LnXn}+u$

Dimana :

$\mathrm{Y}=$ Jumlah total produksi $(\mathrm{kg})$

$\beta 0=$ Konstanta

$\beta \mathrm{i}=$ Elastisitas produksi faktor produksi jagung ke-i $(i=1,2,3,4, \ldots)$

$\mathrm{X} 1$ = Luas lahan yang digunakan $(\mathrm{m} 2)$

$\mathrm{X} 2$ = Penggunaan benih $(\mathrm{kg})$

$\mathrm{X} 3$ = Penggunaan pupuk urea $(\mathrm{kg})$

X4 = Penggunaan pupuk kandang $(\mathrm{kg})$

$\mathrm{X} 5$ = Penggunaan pestisida (1)

X6 = Penggunaan tenaga kerja $(\mathrm{HOK})$

$\mathrm{u}=$ Peubah acak $(\mathrm{u} \leq 0)$

Pengukuran efisiensi diukur dengan menggunakan analisis Data Envelopment Analysis (DEA) memiliki karakter yang berbeda dengan konsep efisiensi pada umumnya. Pertama, efisiensi yang diukur bersifat teknis, bukan alokatif atau 
ekonomis. Artinya, analisis DEA hanya memperhitungkan nilai absolute dari suatu variabel. Oleh karenanya dimungkinkan suatu pola perhitungan kombinasi berbagai variabel dengan satuan yang berbeda-beda. Kedua, nilai efisiensi yang dihasilkan bersifat relatif atau hanya berlaku dalam lingkup petani jagung yang menjadi Unit Kegiatan Ekonomi (UKE) yang diperbandingkan tersebut.

Model DEA digunakan sebagai perangkat untuk mengukur kinerja setidaknya memiliki beberapa keunggulan dibandingkan model lain. Keunggulan tersebut antara lain :

1. Model DEA dapat mengukur banyak variabel input dan banyak variabel output.

2. Tidak diperlukan asumsi hubungan fungsional antara variabel-variabel yang diukur.

3. Variabel input dan output dapat memiliki satuan pengukuran yang berbeda.

Pendekatan parametrik memiliki keunggulan yakni dalam pengukuran inefisiensi melibatkan noise. Akan tetapi, pendekatan parametrik ini membutuhkan penentuan bentuk fungsi produksi yang digunakan seringkali harus dipaksakan agar memenuhi asumsi dasar fungsi produksi. Sebaliknya, metode nonparametrik memiliki keunggulan tidak memerlukan penentuan fungsi produksi sehingga lebih fleksibel dan mudah digunakan (Coelli, 1998). Selain itu, DEA dapat digunakan pada multi output dan multi input. Setiap unit kegiatan ekonomi, dimana dalam penelitian ini merupakan usahatani jagung, menggunakan 6 jenis input produksi, yakni ; luas lahan, benih jagung, pupuk urea, pupuk kandang, pestisida nabati, dan tenaga kerja, serta menghasilkan 1 jenis output yakni produksi jagung.

\section{HASIL DAN PEMBAHSAN}

\section{Analisis Faktor Produksi}

Analisis faktor produksi tanaman jagung ini digunakan untuk mengetahui faktor-faktor apa saja yang berpengaruh secara nyata terahadap hasil produksi jagung. Fungsi produksi yang digunakan dalam penelitian ini adalah model fungsi produksi Cobb-Douglas. Perhitungan analisis fungsi produksi usahatani jagung dapat dijelaskan pada Tabel 1 di bawah ini :

Tabel 1 Hasil Analisis Regresi terhadap Fungsi Produksi Usahatani Jagung

\begin{tabular}{|l|l|l|l|}
\hline \multicolumn{1}{|c|}{ Variabel } & Koefisien regresi & \multicolumn{1}{c|}{ Statistic-t } & \multicolumn{1}{c|}{ Sig.t } \\
\hline Konstanta & 1,680 & 2,545 & 0,030 \\
Luas Lahan (LnX1) & 0,862 & 7,552 & $0,000^{*}$ \\
Benih (LnX2) & 0,213 & 4,213 & $0,005^{*}$ \\
Pupuk Urea (LnX3) & $-0,028$ & $-0,667$ & 0,745 \\
\hline
\end{tabular}




\begin{tabular}{|l|l|l|l|}
\hline \multicolumn{1}{|c|}{ Variabel } & Koefisien regresi & \multicolumn{1}{|c|}{ Statistic-t } & \multicolumn{1}{c|}{ Sig.t } \\
\hline Pupuk Kandang (LnX4) & 0,085 & 3,285 & $0,042^{*}$ \\
Pestisida (LnX5) & 0,067 & 1,388 & 0,274 \\
Tenaga Kerja (LnX6) & $-0,034$ & $-0,649$ & 0,688 \\
\hline \multicolumn{1}{|c|}{$\mathrm{R}^{2}$} & \multicolumn{3}{|c}{0,968} \\
Statistic - F & \multicolumn{3}{|c}{117,342} \\
DW - Statistis & \multicolumn{3}{|c}{1,942} \\
\hline
\end{tabular}

\section{Sumber: Data Primer Diolah, 2011.}

Keterangan :

* : signifikan pada taraf kesalahan sebesar $0,05(5 \%)$

Berdasarkan hasil pada Tabel 12, persamaan regresi yang terbentuk adalah sebagai berikut :

$\operatorname{Ln} Y=1,680+0,862 \operatorname{Ln} X 1+0,213 \operatorname{Ln} X 2-$

$0,028 \operatorname{LnX} X+0,085 \operatorname{Ln} X 4+0,067 \operatorname{Ln} X 5$ -

\section{$0,034 \operatorname{LnX} 6$}

Di mana :

LnY : Hasil Produksi Jagung ( Kg)

LnX1 : Luas Lahan (m2)

LnX2 : Benih $(\mathrm{Kg})$

LnX3 : Pupuk Urea (Kg)

LnX4 : Pupuk Kandang (Kg)

LnX5 : Pestisida (L)

LnX6 : Tenaga Kerja (HOK)

Faktor-faktor produksi yang digunakan dalam usahatani jagung di daerah penelitian adalah luas lahan, benih, pupuk urea, pupuk kandang, pestisida dan tenaga kerja. Dari keenam variabel tersebut yang berpengaruh nyata pada usahatani jagung adalah luas lahan, benih, pupuk kandang. Hal ini berarti bahwa dengan adanya penambahan luas lahan, benih, pupuk kandang akan berpengaruh lebih besar terhadap produksi jagung dibandingkan faktor produksi lainnya. Sementara itu, faktor luas lahan, penggunaan benih, penggunaan pupuk kandang dan pestisida memiliki hubungan yang positif sedangkan faktor penggunaan pupuk urea dan tenaga kerja memiliki hubungan yang negatif terhadap produksi jagung yang dihasilkan.

\section{Analisis Efisiensi Teknis Usahatani Jagung}

Analisis efisiensi teknis dilakukan melalui pendekatan Data Envelopment Analysis (DEA) dengan orientasi input dan variable return to scale. Variabel output yang digunakan yaitu hasil produksi jagung (Y), sedangkan variabel input yang digunakan adalah luas lahan (X1), benih (X2), pupuk urea (X3), pestisida (X4), dan tenaga kerja (X5). Berdasarkan hasil perhitungan menggunakan DEAP versi 2.1, diperoleh hasil yang menunjukkan bahwa persentase responden yang memiliki nilai efisiensi sama dengan satu sebesar 41,94 persen, sedangkan persentase responden yang memiliki nilai efisiensi kurang dari satu sebesar 58,06 
persen dari total responden (untuk model DEA VRS). Nilai efisiensi teknis petani jagung di Desa Sukolilo bervariasi antara 40,3 persen hingga 100 persen (Tabel 2). Output lain yang diperoleh dari perhitungan dengan menggunakan Data Envelopment Analysis (DEA) yaitu diperolehnya keterangan yang menunjukkan kecenderungan tren pada petani di lokasi penelitian tergolong pada increasing return to scale (IRS), decreasing return to scale (DRS), atau constant return to scale (CRS). Petani yang berada pada posisi meningkatkan skala pengembaliannya (increasing return to scale) berada di posisi dimana peningkatan output lebih besar daripada peningkatan input. Sedangkan petani yang berada pada posisi penurunan skala pengembaliannya (decreasing return to scale) berada di posisi dimana peningkatan output lebih kecil daripada peningkatan input produksi. Petani responden yang tergolong pada increasing return to scale (IRS) sebanyak 18 orang (58,06 persen), sebanyak 3 orang (9,68 persen) tergolong pada decreasing return to scale (DRS), dan sebanyak 10 orang (32,26 persen) tergolong pada constant return to scale (CRS).

Tabel 2. Efisiensi Teknis Model VRS Usahatani Jagung

\begin{tabular}{|c|c|c|c|c|}
\hline No. & Nama UKE & Nilai Efisiensi Teknis (\%) & Keterangan & Skala Efisiensi \\
\hline 1. & UKE 1 & 88,4 & Tidak Efisien & IRS \\
\hline 2. & UKE 2 & 95,4 & Tidak Efisien & IRS \\
\hline 3. & UKE 3 & 100 & Tidak Efisien & IRS \\
\hline 4. & UKE 4 & 100 & Efisien & CRS \\
\hline 5. & UKE 5 & 100 & Efisien & CRS \\
\hline 6. & UKE 6 & 64,7 & Tidak efisien & IRS \\
\hline 7. & UKE 7 & 71,4 & Tidak efisien & IRS \\
\hline 8. & UKE 8 & 100 & Efisien & CRS \\
\hline 9. & UKE 9 & 78,4 & Tidak Efisien & IRS \\
\hline 10 & UKE 10 & 100 & Efisien & CRS \\
\hline 11. & UKE 11 & 100 & Efisien & CRS \\
\hline 12 . & UKE 12 & 100 & Efisien & CRS \\
\hline 13. & UKE 13 & 62,8 & Tidak Efisien & IRS \\
\hline 14. & UKE 14 & 100 & Efisien & CRS \\
\hline 15. & UKE 15 & 100 & Efisien & IRS \\
\hline 16. & UKE 16 & 58,3 & Tidak Efisien & IRS \\
\hline
\end{tabular}




\begin{tabular}{|c|c|c|c|c|}
\hline No. & Nama UKE & Nilai Efisiensi Teknis (\%) & Keterangan & Skala Efisiensi \\
\hline 17. & UKE 17 & 40,3 & Tidak Efisien & IRS \\
\hline 18. & UKE 18 & 61,8 & Tidak Efisien & IRS \\
\hline 19. & UKE 19 & 100 & Efisien & DRS \\
\hline 20. & UKE 20 & 100 & Efisien & CRS \\
\hline 21. & UKE 21 & 92,5 & Tiadak Efisien & IRS \\
\hline 22. & UKE 22 & 99,6 & Tidak Efisien & IRS \\
\hline 23. & UKE 23 & 98,3 & Tidak Efisien & IRS \\
\hline 24. & UKE 24 & 69,3 & Tidak Efisien & DRS \\
\hline 25. & UKE 25 & 100 & Efisien & CRS \\
\hline 26. & UKE 26 & 85,8 & Tidak Efisien & IRS \\
\hline 27. & UKE 27 & 73,9 & Tidak Efisien & DRS \\
\hline 28. & UKE 28 & 76,4 & Tidak Efisien & IRS \\
\hline 29. & UKE 29 & 88,2 & Tidak Efisien & IRS \\
\hline 30. & UKE 30 & 100 & Efisien & CRS \\
\hline 31. & UKE 31 & 90,1 & Tidak Efisien & IRS \\
\hline & Rata-rata & \multicolumn{3}{|c|}{$87 \%$} \\
\hline & Minimum & \multicolumn{3}{|c|}{$40,3 \%$} \\
\hline & Maksimum & \multicolumn{3}{|c|}{$100 \%$} \\
\hline
\end{tabular}

\section{Sumber: Data Primer Diolah, 2011.}

Pengukuran efisiensi menggunakan

Data Envelopment Analysis (DEA) menunjukkan bahwa usahatani jagung di daerah penelitian belum mampu mencapai performansi tingkat efisiensi yang fullefisien secara teknis, karena rata-rata efisiensi teknis yang dicapai sebesar $87 \%$, dengan kisaran antara 40,3\% hingga 100\%. Hal ini mengindikasikan masih adanya peluang bagi petani jagung untuk untuk meningkatkan hasil produksinya dengan mengoptimalkan faktor-faktor produksi yang dimiliki, misalnya penerapan teknologi, penggunaan mesin traktor pada pengolahan lahan. Return to Scale). Agar petani yang beroperasi pada skala DRS dapat beroperasi secara optimal (CRS), maka petani dapat melakukan minimalisasi penggunaan input. Sedangkan petani yang beroperasi pada skala IRS dapat beroperasi secara optimal (CRS), maka petani dapat mengoptimalkan penggunaan input yang dimiliki.Selain itu, dalam analisis DEA (Data Envelopment Analysis) responden yang tidak efisien dapat melakukan perbandingan dengan responden yang sudah efisien secara teknis untuk memperbaiki penggunaan input-input 
produksinya. Petani responden yang memiliki nilai efisiensi sama dengan satu merupakan petani yang memiliki kinerja terbaik apabila dibandingkan dengan responden lainnya. Petani responden dengan kinerja terbaik ini akan dijadikan sebagai pembanding (benchmark) bagi responden lainnya. Berdasarkan Tabel 1., terlihat bahwa petani responden nomor satu (yang belum efisien secara teknis) dapat dibandingkan dengan tiga petani responden lainnya yang telah efisien secara teknis.

\section{KESIMPULAN}

Berdasakan hasil analisis yang telah dilakukan, maka dapat disimpulkan beberapa hal dari penelitian ini, yaitu :

1. Faktor-faktor produksi yang digunakan dalam usahatani jagung di daerah penelitian adalah luas lahan, benih, pupuk urea, pupuk kandang, pestisida dan tenaga kerja. Dari keenam variabel tersebut yang berpengaruh nyata pada usahatani jagung adalah luas lahan, benih, pupuk kandang. Hal ini berarti bahwa dengan adanya penambahan luas lahan, benih, pupuk kandang akan berpengaruh lebih besar terhadap produksi jagung dibandingkan faktor produksi lainnya. Sementara itu, faktor luas lahan, penggunaan benih, penggunaan pupuk kandang dan pestisida memiliki hubungan yang positif sedangkan faktor penggunaan pupuk urea dan tenaga kerja memiliki hubungan yang negatif terhadap produksi jagung yang dihasilkan.

2. Pengukuran efisiensi menggunakan Data Envelopment Analysis

(DEA) menunjukkan bahwa usahatani jagung di daerah penelitian belum mampu mencapai performansi tingkat efisiensi yang fullefisien secara teknis, karena rata-rata efisiensi teknis yang dicapai sebesar $87 \%$, dengan kisaran antara 40,3\% hingga $100 \%$. Nilai inefisiensi teknis rata-rata adalah sebesar $13 \%$. Hal ini mengindikasikan masih adanya peluang bagi petani jagung untuk untuk meningkatkan hasil produksinya dengan mengoptimalkan faktor-faktor produksi yang dimiliki, misalnya penerapan teknologi, penggunaan mesin traktor pada pengolahan lahan.

\section{SARAN}

Beberapa saran yang diajukan berkenaan dengan hasil penelitian ini adalah sebagai berikut :

1. Untuk mengatasi kurang optimalnya penggunaan faktor produksi luas lahan dapat dilakukan perbaikan sistem budidaya dan pengolahan tanah. Hal ini disebabkan karena perluasan lahan pertanian di daerah penelitian sulit dilakukan. Selain itu perluasan lahan tidak akan mampu meningkatkan produksi dan keuntungan petani apabila sistem budidaya dan pengelolaan tanahnya kurang baik. 
2. Perlu dilakukan upaya untuk mengefisienkan penggunaan faktor produksi dalam usahatani jagung mengingat bahwa di daerah penelitian belum mampu mencapai full efisien secara teknis.

\section{DAFTAR PUSTAKA}

Coelli, Timothy J., Rao, DS Prasada., O'Donell, Christopher J., Battesse, George E. 1998. An Introduction to Efficiency and Productivity Analysis. Springer. USA.
Departemen Pertanian. 2002. Pedoman Umum Pemanfaatan Bantuan Langsung Masyarakat. Departemen Pertanian, Jakarta.

Soekartawi, 1990. Teori Ekonomi Produksi dengan Pokok Bahasan Analisis Fungsi Cobb-Douglas. Rajawali Press, Jakarta.

Suprapto, H.S dan A.R Marzuki. 2005. Bertanam Jagung. Penebar Swadaya. Jakarta

Suwito. 1996. Sosiolinguistik. Surakarta: UNS Press 